OPEN ACCESS

Edited by:

Thomas Bartholomäus Brück, Technische Universität München,

Germany

Reviewed by: Ashokkumar Balasubramaniem, Madurai Kamaraj University, India Wolfram Manuel Brück University of Applied Sciences and Arts of Western Switzerland,

Switzerland

*Correspondence: Hossein Ahmadzadeh h.ahmadzadeh@um.ac.ir

Specialty section:

This article was submitted to Bioprocess Engineering, a section of the journal Frontiers in Bioengineering and Biotechnology

Received: 26 October 2018 Accepted: 20 February 2019 Published: 19 March 2019

Citation:

Molazadeh M, Ahmadzadeh H,

Pourianfar HR, Lyon S and Rampelotto PH (2019) The Use of Microalgae for Coupling Wastewater Treatment With $\mathrm{CO}_{2}$ Biofixation. Front. Bioeng. Biotechnol. 7:42. doi: 10.3389/fbioe.2019.00042

\section{The Use of Microalgae for Coupling Wastewater Treatment With $\mathrm{CO}_{2}$ Biofixation}

\author{
Marziyeh Molazadeh ${ }^{1}$, Hossein Ahmadzadeh ${ }^{2 *}$, Hamid R. Pourianfar ${ }^{3}$, Stephen Lyon $^{4}$ and \\ Pabulo Henrique Rampelotto ${ }^{5}$ \\ ${ }^{1}$ Faculty of Engineering, Department of Civil Engineering, Ferdowsi University of Mashhad, Mashhad, Iran, ${ }^{2}$ Faculty of \\ Science, Department of Chemistry, Ferdowsi University of Mashhad, Mashhad, Iran, ${ }^{3}$ Culture and Research \\ (ACECR)-Khorasan Razavi Branch, Industrial Fungi Biotechnology Research Department, Academic Center for Education, \\ Mashhad, Iran, ${ }^{4}$ SRL-Environmental, LLC, Racine, WI, United States, ${ }^{5}$ Center of Biotechnology and PPGBCM, Federal \\ University of Rio Grande do Sul, Porto Alegre, Brazil
}

Production and emission of $\mathrm{CO}_{2}$ from different sources have caused significant changes in the climate, which is the major concern related to global warming. Among other $\mathrm{CO}_{2}$ removal approaches, microalgae can efficiently remove $\mathrm{CO}_{2}$ through the rapid production of algal biomass. In addition, microalgae have the potential to be used in wastewater treatment. Although, wastewater treatment and $\mathrm{CO}_{2}$ removal by microalgae have been studied separately for a long time, there is no detailed information available on combining both processes. In this review article, microalgae-based $\mathrm{CO}_{2}$ biofixation, various microalgae cultivation systems; and microalgae-derived wastewater treatment are separately discussed, followed by the concept of integration of $\mathrm{CO}_{2}$ biofixation process and wastewater treatment. In each section, details of energy efficiency and differences across microalgae species are also given.

Keywords: microalgae, carbon dioxide biofixation, wastewater treatment, biomass production, global warming

\section{INTRODUCTION}

Global warming is one of the major concerns for many countries around the world. This issue has mainly been attributed to high concentrations of gases where carbon dioxide $\left(\mathrm{CO}_{2}\right)$ is the largest contributor, being responsible for up to 60 percent of the total greenhouse gases (E. I. A. U.S. Department of Energy, 1997; Yamasaki, 2003; Coyle, 2007). $\mathrm{CO}_{2}$ concentration in the atmosphere has increased from pre-industrial levels of $280 \mathrm{ppm}$ to about $400 \mathrm{ppm}^{\text {today }}{ }^{1}$ A major part of this noticeable increase lies in the growing demands for fossil fuels in energy and transportation sectors. It is anticipated that atmospheric $\mathrm{CO}_{2}$ levels will continue to rise to about $570 \mathrm{ppm}$ by Twenty-Second century (Stewart and Hessami, 2005). Consequently, the world temperature could increase by $1.9^{\circ} \mathrm{C}$, while the sea level could experience an average increase of $3.8 \mathrm{~m}$ (Stewart and Hessami, 2005). Due to increasing concerns about the greenhouse gases-caused climate change, the Kyoto protocol was established as the first agreement between world nations to mandate country-by-country reductions in greenhouse gas emissions at 1997.

Since $\mathrm{CO}_{2}$ is the largest contributor to the greenhouse effect, a reduction in $\mathrm{CO}_{2}$ level will directly affect the total greenhouse gas emissions. Currently, three major methods are being taken into action in order to remove excess atmospheric $\mathrm{CO}_{2}$ : (i) the use of chemical reactions including chemical/physical solvent scrubbing, adsorption, cryogenics, and membranes, (ii) The storage of

\footnotetext{
${ }^{1}$ http://www.esrl.noaa.gov/gmd/ccgg/trends/global.html
} 
$\mathrm{CO}_{2}$ emitted underground or into the ocean (Kumar et al., 2010), and (iii) Transforming $\mathrm{CO}_{2}$ to organic matters through biological mitigation.

Chemical methods are not environmentally sustainable and require considerable space and investment. In addition, the most noticeable challenge with the storage method could be the potential for $\mathrm{CO}_{2}$ leakage over the years (Lackner, 2003). Accordingly, the biological mitigation is an economically practical and environmentally sustainable technology which has achieved much attention as an alternative method in the long term (Kumar et al., 2010). Biological $\mathrm{CO}_{2}$ fixation usually occurs through photosynthesis by terrestrial plants and trees. However, they are able to eliminate only 3-6 percent of $\mathrm{CO}_{2}$ because of their slow growth, while other microorganisms such as eukaryotic algae and cyanobacteria can fix $\mathrm{CO}_{2} \quad 10-50$ times faster (Iasimone et al., 2017). Algae are capable of eliminating 513 tons of $\mathrm{CO}_{2}$ and producing up to 100 tons of dry biomass per hectare per year (Bilanovic et al., 2009). Another advantage with algae lies in the production of renewable fuels such as biodiesel and hydrogen. Since $\mathrm{CO}_{2}$ emitted during combustion of these biofuels can be assimilated by the algae, there is a resulting net zero balance of $\mathrm{CO}_{2}$ emissions (Kumar et al., 2010). Furthermore, algae can be a source of nutrition (Sabra et al., 2001; Becker, 2007; Plaza et al., 2008; Raja et al., 2008; Dvir et al., 2009; Gressler et al., 2010) including vitamins (Lee, 2001; Raja et al., 2008), minerals (Lee, 2001; Dvir et al., 2009), and proteins (Raja et al., 2008; Dvir et al., 2009) which in turn may help to offset the cost of $\mathrm{CO}_{2}$ bioremediation.

Microalgal species can treat municipal, industrial, agroindustrial, and livestock wastewaters. Microalgal systems for the treatment of other wastes such as the effluent from food processing and other agricultural wastes have been also reported in the literature. Furthermore, algae-based strategies for the removal of toxic minerals such as $\mathrm{As}, \mathrm{Br}, \mathrm{Cd}, \mathrm{Hg}, \mathrm{Pb}, \mathrm{Sc}$, and $\mathrm{Sn}$ ions have also been reported individually or in a mixture (Abdel-Raouf et al., 2012).

Many microalgae species have been adapted to grow efficiently in wastewater. This way, the cost of production may be decreased due to the simultaneous use of wastewater and cultivation of specific nutrient-rich microalgae. Therefore, microalgae-mediated $\mathrm{CO}_{2}$ bio-mitigation can be more economic, cost-effective, and eco-friendly, when it is incorporated into a wastewater treatment infrastructure (Kuo et al., 2016; Collotta et al., 2018).

In this chapter, several issues related to the use of microalgae for $\mathrm{CO}_{2}$ biofixation and wastewater treatment are discussed. Details with regard to $\mathrm{CO}_{2}$ removal techniques, microalgae cultivation systems, wastewater treatment methods, and evaluation of the integration of carbon capture technology to wastewater treatment are provided.

\section{CARBON DIOXIDE REMOVAL STRATEGIES}

\section{Non-biological Methods \\ Carbon Dioxide Sequestration}

By definition, $\mathrm{CO}_{2}$ sequestration is a long-term $\mathrm{CO}_{2}$ process in order to decrease the level of $\mathrm{CO}_{2}$ emitted to the atmosphere. In this regard, there are various storage approaches that could be taken into account, including: mineralization, ocean storage, and geological storage. These storage methods also should comply with the following specifications: (i) safe storage, (ii) minimal environmental impact (iii) verifiable storage (iv) indefinite storage (Lackner and Brennan, 2009).

Mineralization is a process by which gaseous $\mathrm{CO}_{2}$ is transformed to solid inorganic carbonates by chemical reactions. Among others, calcium and magnesium silicates can uptake $\mathrm{CO}_{2}$ from the atmosphere through the process of carbonate formation, leading to a permanent storage of the $\mathrm{CO}_{2}$. This process offers a sustainable opportunity to safely store $\mathrm{CO}_{2}$ during a long period. However, it is obviously very slow in nature and thus a high cost of technology may be needed to speed up this process (Allen and Brent, 2010).

The ocean is considered to be the largest natural reservoir of $\mathrm{CO}_{2}$ (Khoo and Tan, 2006) so that the injection of all the anthropogenic $\mathrm{CO}_{2}$ would change the ocean carbon concentration and $\mathrm{pH}$ by less than $2 \%$ and 0.15 units, respectively (Herzog and Golomb, 2004). The natural ocean storage process consists of transporting captured $\mathrm{CO}_{2}$ to the deep ocean. However, concerns have been raised by environmentalists with regard to environmental impacts of $\mathrm{CO}_{2}$ stored in the ocean, including serious effects on marine life and acidification of water. The mass discharges of $\mathrm{CO}_{2}$ are considered by some to be the equivalent of uncontrolled dumping of toxic waste into the world oceans. (Herzog and Golomb, 2004)

The option of storing $\mathrm{CO}_{2}$ beneath the earth's surface holds greater potential for controlled conditions with the least environmental impact. The storage locations could include saline aquifers, spent oil and natural gas wells that are no longer in production and unmineable coal seams (Celia et al., 2009). Given the fact that human activity generates almost seven gigatons of carbon ( $\mathrm{GtC}$ ) per year, this storage option could accommodate hundreds to thousands of total GtC stored beneath the earth. ( $1 \mathrm{GtC}=1$ billion metric tons of carbon equivalent) (Herzog and Golomb, 2004).

There are direct environmental and human health risks raised by environmentalists, including leaks, slow migration and accumulation and induced seismicity.

\section{Carbon Dioxide Capture Approaches}

For the past 40 years, fossil fuels have been blamed as the source for generating a significant portion of the anthropogenic $\mathrm{CO}_{2}$ in the atmosphere. Therefore, it is reasonable to capture $\mathrm{CO}_{2}$ from fossil fuels-dependent industrial operations in order to significantly decrease the atmospheric $\mathrm{CO}_{2}$ levels. The captured $\mathrm{CO}_{2}$ could be used in different industries, such as urea production, foam blowing, carbonating beverages, and the production of dry ice. Currently, the three main approaches of $\mathrm{CO}_{2}$ capture are (Pires et al., 2011): post-combustion, oxy-fuel combustion, and pre-combustion.

\section{Pre-combustion}

Pre-combustion is normally applied in integrated gasification combined cycle (IGCC) power plants. The process uses a high-pressure gasifier to convert coal into 


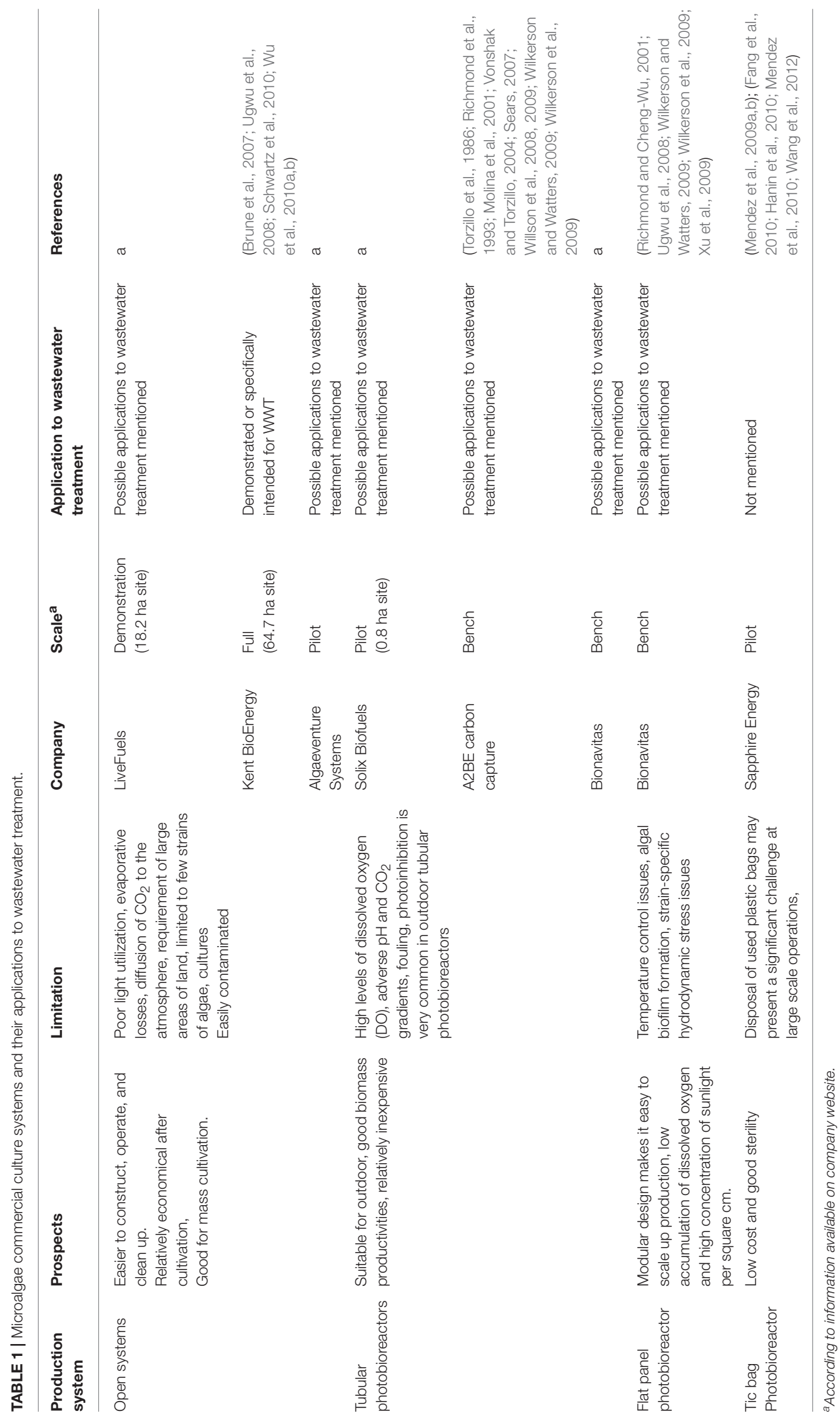


pressurized gas, composed of $\mathrm{CO}$ and $\mathrm{H}_{2}$. The $\mathrm{CO}_{2}$ will be captured from the synthesized gases, releasing $\mathrm{H}_{2}$ to be used further as the fuel in a gas turbine to produce electricity (Pachauri and Reisinger, 2007). A major limitation with this method is that the cost of electricity generated in pulverized coal (PC) power plants is lower than the costs in IGCC plants. An additional difficulty is that the pre-combustion process occurs only where methane is the main fuel.

II. Oxy-Fuel Combustion

In oxy-fuel combustion, the fuel is mixed with pure oxygen in a nitrogen free environment that results in a flue exhaust gas containing $\mathrm{CO}_{2}$ and water vapor. This way, the captured $\mathrm{CO}_{2}$ can be stored with less downstream processing.

III. Post-combustion

Among the $\mathrm{CO}_{2}$ capture technologies, the time needed for the development of coal-derived

Syngas separation, hydrogen turbine, and fuel-cell technologies significantly decreases if a post-combustion method is implemented. Unlike pre-combustion, postcombustion can be fitted to fossil fuel-fired power plants (Pires et al., 2011). Presently, post-combustion capture can be performed employing several technologies as explained below (Pires et al., 2011).

\section{○ Adsorption}

Adsorption includes diffusing molecules, atoms, or ions of a gas or a liquid to the surface of a solid, where they may bond with the solid surface or establish weak intermolecular forces. The Intermolecular forces between gases and the surfaces of certain solid materials would be the main process in $\mathrm{CO}_{2}$ adsorption. This is dependent on various factors such as temperature, partial pressures, surface forces, adsorbent pore sizes, and the selectivity of the adsorbent material (Xiao et al., 2008).

Adsorption can be processed through either chemical bonds or physical forces. Chemical bonds are composed an immobilized amine or other reactants on a support surface. The adsorbent reacts with the $\mathrm{CO}_{2}$ in the flue gas (Pires et al., 2011). Physical adsorption works based on the intensity of intermolecular forces, where the forces between molecules of a solid and the flue gas are greater than those between molecules of the gas itself (Pires et al., 2011).

Thus far, several chemical and physical materials have been proposed to serve as adsorbents, including carbon fiber monolithic adsorbents (Thiruvenkatachari et al., 1997), activated carbon fiber-phenolic resin composites, melamine-formaldehyde highly porous adsorbent, and amine immobilized adsorbents (Meisen and Shuai, 1997).

- Membrane separation

With regard to $\mathrm{CO}_{2}$ removal, two major kinds of membranes are normally used; gas separation and gas absorption membranes. Gas separation contains solid membranes that operate based on of a porous structure that allows the preferential permeation of mixture constituents (Meisen and Shuai, 1997). The separation process is a function of both time and the physical/chemical properties of the membrane that favors one part of the gas mixture over the other at a fixed rate of gas permeation.

$\mathrm{CO}_{2}$ is taken up on one side of the membrane, diffuses through it and is released on the other side (Pires et al., 2011). Gas absorption membranes are micro porous solid membranes that need to be in contact with an adsorbent, such as a liquid (Meisen and Shuai, 1997). The absorption liquid on one side of the membrane selectively takes up $\mathrm{CO}_{2}$ from the mixed gas stream on the other side of the membrane (Pires et al., 2011).

Gas absorption membranes can be grouped into polymer membranes, palladium membranes, and molecular sieves (Pires et al., 2011).

\section{- Cryogenic separation}

A temperature-based approach can be used for the select removal and concentration of $\mathrm{CO}_{2}$ (Pires et al., 2011). The use of cryogenic processes, also known as low temperature distillation, to remediate flue gas emission is still at its early stages. This involves cooling and liquefying concentrated $\mathrm{CO}_{2}$ in a stream gas through several stages to eventually induce phase changes in $\mathrm{CO}_{2}$ (Meisen and Shuai, 1997). This method is more effective for gases stored at ambient or lower temperature with high concentrations ( $>50 \%)$. Thus, it may not be economically recommended for diluted gases containing $\mathrm{CO}_{2}$ such those emitted by coal-fired plants (Herzog and Golomb, 2004).

- Absorption

Carbon dioxide can be removed through an absorption system, comprised of two components; the absorber and the stripper (desorber) (Erga et al., 1995). The absorption system operates on physical, chemical or hybrid absorption processes. In chemical absorption, $\mathrm{CO}_{2}$ is absorbed by a liquid solvent that forms a temporary chemical bond with the gas. $\mathrm{CO}_{2}$ then reacts with one or more basic chemical absorbent to form a weakly bonded intermediate compound. This compound is then broken down by heat, regenerating the original absorbent and producing a $\mathrm{CO}_{2}$ stream (Erga et al., 1995). In industrial settings, $\mathrm{CO}_{2}$ separates from the gas stream by bubbling into a liquid absorbent in a packed absorber column. The absorbed $\mathrm{CO}_{2}$ is stripped out of the chemical solvent by a counter flowing steam at $100-120^{\circ} \mathrm{C}$ passing through a regenerator unit. In order to remove water vapor from the stream it should be condensed resulting in the highly concentrated (over 99\%) $\mathrm{CO}_{2}$. The solvent is cooled to $40-65^{\circ} \mathrm{C}$ and recycled into the absorption column. Typical absorbents commercially available in a chemical absorption system include amine carbonate-based components such as mono-ethanolamine (MEA), diethanolamine (DEA), ammonia and hot potassium carbonate (Erga et al., 1995).

According to Henry's law, physical absorption-based $\mathrm{CO}_{2}$ removal is performed through physically absorption to a solvent followed by regeneration applying heat and/or pressure reduction. Some of the commercially available physical absorbents include Selexol (dimethylether of polyethylene glycol) and Rectisol (cold methanol) which are applied at high pressure.

In addition to the physical or chemical absorption, a combination of the best characteristics of both methods 
can also be utilized, known as hybrid absorption. Several commercial absorbent have been used to serve as hybrid absorption, including Sulfinol (a composite solvent, including a mixture of diisopropanolamine (30-45\%) or methyl diethanolamine (MDEA), sulfolane (tetrahydrothiophene dioxide) (40-60\%), and water (5-15\%) (Desideri and Corbelli, 1998).

\section{Carbon Dioxide Biofixation Using Microalgae}

Near half of the dry biomass weight of microalgae is made of carbon, thus the carbon content in a microalgae growth medium in dissolved or gaseous form is crucial and often a limiting factor for maximal productivity. The concentration of $\mathrm{CO}_{2}$ in the atmosphere (only about $0.04 \% v / v$ ) is not sufficient to provide carbon for algal growth. Microalgae are naturally able to attain their carbon from several other sources, including $\mathrm{CO}_{2}$ from industrial flue gases, and those chemically fixed in soluble carbonate compounds (e.g., $\mathrm{NaHCO}_{3}$ and $\mathrm{Na}_{2} \mathrm{CO}_{3}$ )(He et al., 2016). The main concept is that microalgae utilize $\mathrm{CO}_{2}$ as its main carbon source for a wide array of metabolic processes. Waste gases from combustion represent a viable source of $\mathrm{CO}_{2}$ that can be directly introduced into large-scale microalgae production systems, as they usually contains $\mathrm{CO}_{2}$ in volume fraction of 5 to $15 \%$. In addition, the $\mathrm{CO}_{2}$ converted in the form of algal biomass can be further used as food, feed, fertilizer, or fuel. Processes including digestion, respiration and combustion of the biomass could release $\mathrm{CO}_{2}$ back into the air. Thus, it would be logical to assume that microalgae are not simply $\mathrm{CO}_{2}$ reservoir but they act like a biological post-combustion tool for capturing $\mathrm{CO}_{2}$ from flues gases emitted from power plants.

Microalgae-derived $\mathrm{CO}_{2}$ biofixation can promote production of valuable algal biomass and simultaneously reduce greenhouse gas emissions. However, little progress has been made to lower the cost of this approach (Herzog and Golomb, 2004). The most important advantage of $\mathrm{CO}_{2}$ fixation by microalgae is their rapid and widespread growth. In addition, biofuel produced by microalgae is highly biodegradable and contains no sulfur or toxic materials (Demirbas, 2011).

Tolerance to the $\mathrm{CO}_{2}$ concentrations of a flue gas has been shown to be different across different microalgae species. Limited groups of microalgae have shown extraordinary tolerance of high concentration of $\mathrm{CO}_{2}$, including Chlorella spp., Arthrospira (formerly Spirulina) spp., Scenedesmus dimorphus, Botryococcus braunii, and Nannochloropsis oculate (Cheah et al., 2015). Under high $\mathrm{CO}_{2}$ concentrations (10-80\%), Scenedesmus spp. showed more tolerance than Chlorella spp., while both species were able to grow in lower $\mathrm{CO}_{2}$ concentrations (10-30\%). However, Scenedesmus spp. growth was prevented under $100 \% \mathrm{CO}_{2}$ concentration (Hanagata et al., 1992). A mutant of Chlorella spp. (strain KR-1) was reported to grow even under $\mathrm{CO}_{2}$ levels as high as 70\% (Sung et al., 1998). Flue gases from a coke oven, hot stove, and power plant in a steel plant was used for Chlorella sp. MFT-15 cultivation. The maximum average specific growth and lipid production were reported to be $0.77 /$ day and $0.81 \mathrm{~g} / \mathrm{L}$, respectively. The findings revealed that Chlorella sp. MFT-15 could efficiently utilize the $\mathrm{CO}_{2}, \mathrm{NO}_{\mathrm{X}}$, and $\mathrm{SO}_{2}$ present in the different flue streams (Kao et al., 2014). Another study showed an excellent tolerance in $S$. dimorphus to stream gas containing high levels of $\mathrm{CO}_{2}(2-20 \%), \mathrm{NO}(150-500 \mathrm{ppm})$, and $\mathrm{SO}_{2}(100$ ppm)(Jiang et al., 2013).

The rate of $\mathrm{CO}_{2}$ fixation by microalgae might also be different across various species or even mutated strains of the same species. Evaluation of five different microalgae suitable for mass cultivation showed significant differences in $\mathrm{CO}_{2}$ fixation rates as follows: Dunaliella tertiolecta SAD-13.86 (272.4 $\mathrm{mg} / \mathrm{L} /$ day), Chlorella vulgaris LEB-104 (251.64 mg /L/day), Spirulina platensis LEB-52 (318.61 mg/L/day), Botryococcus braunii SAG-30.81 (496.98 mg/L/day), and Chlorococcum littorale (1,000 mg/L/day) (Sydney et al., 2010). While C. vulgaris fixed $\mathrm{CO}_{2}$ emitted from flue gas up to $260 \mathrm{mg} / \mathrm{L} / \mathrm{h}$ (Larsson and Lindblom, 2011), C. sorokiniana yielded $330 \mathrm{mg} \mathrm{L}^{-1}$ after $96 \mathrm{~h}$ of exposure to flue gas containing $\mathrm{CO}_{2}$ (Lizzul et al., 2014). It was also found that a mutant strain of Scenedesmus obliquus WUST4 captured $\mathrm{CO}_{2}$ from flue gas and accumulated a high biomass concentration $(0.922 \mathrm{~g} / \mathrm{L})$ under $10 \% \mathrm{CO}_{2}$ concentrations, as compared to that of the non-mutant S. obliquus $(0.653 \mathrm{~g} / \mathrm{L})$ under higher concentration of $\mathrm{CO}_{2}$ (20\%) (Li et al., 2011).

\section{MICROALGAE CULTIVATION SYSTEM TECHNOLOGY}

The type of final products, the source of nutrients, the criteria for cultivation $\left(\mathrm{CO}_{2}\right.$ capture, biofuels, etc.) and the capital cost (CC) and operation and maintenance (O\&M) are the driving forces behind the diversity in cultivation systems described in the literature. The cultivation systems of microalgae could be classified into two major conditions: "open" or "closed" systems, even though sometimes these groups might overlap. In essence, the "open" systems (such as ponds, lagoons, and deep channels) are usually established outdoors. The "closed" systems are usually located indoor under artificial light or outdoors under sunlight and should include vessels or tubes with walls made of transparent materials. These cultivation systems and the industrial scale production for each system have been compared and summarized in Table 1.

\section{Open Systems}

Historically, open ponds are used in commercial-scale algae production due to their low construction costs and ease of operation (Cai et al., 2013). In general, these systems can be classified into natural or artificial water systems. In natural water systems, algae production occurs in lakes, lagoons, and ponds. Artificial water systems occur in a variety of sizes, offer a greater degree of environmental controls and include man-made ponds, tanks, and various above ground and below ground containers (Ugwu et al., 2008).

In addition, different shapes, sizes, and types of open systems have been devised depending on the application (Tredici, 2004). Most importantly, open systems could be classified as nonstirred and stirred ponds in terms of aeration and distribution of nutrient in the media. In short, non-stirred ponds are more 
economical and simpler to manage, while stirred ponds provide proper aeration, light, and distribution of nutrients that in turn improve the growth of microalgae.

\section{Non-stirred Ponds}

Non-stirred ponds with an average depth of one half meter or less are the simplest of intermediate to large-scale culturing facilities. More than 30 tons per year (dry weight) of algae are harvested from non-stirred ponds and lakes in South-East Asia (Lee, 1997). Non-stirred ponds are subject to the same processes in natural ponds that include predation by zooplankton, mixed algal populations and well as the potential growth of pathogens (protozoans and bacteria) (Chaumont, 1993).

Accordingly, there are limited number of microalgae species, namely Dunaliella salina (Benemann et al., 1987; Borowitzka and Borowitzka, 1990) that have been grown commercially using this method.

\section{Stirred Ponds}

The most common forms of stirred ponds are high rate algal ponds (HRAP) and circular ponds. HRAP, also known as raceway ponds (Tredici, 2004) are open and shallow (15-25 cm deep) where the water is circulated with a paddlewheel. The raceways are constructed with either individual or multiple channels in a closed loop (Razzak et al., 2013). Some researchers obtain biomass concentrations of up to $1 \mathrm{~g}$ dry weight/L and 60$100 \mathrm{mg}$ dry weight/L/d productivities in raceway ponds (Becker, 1994; Lee, 1997; Tredici, 2004). Raceway ponds are regularly utilized for the industrial culturing of Chlorella spp., Arthrospira platensis, Hematococcus spp., and D. salina (Moheimani and Borowitzka, 2006). Generally, constructing raceways are still inexpensive compared to many forms of closed systems, nevertheless raceways suffer from low productivity because of algal contamination, poor mixing efficiency, inefficient use of $\mathrm{CO}_{2}$ and shading effect (Chisti, 2007; Mata et al., 2010).

In South-East Asia, circular ponds with a central pivot are used for the production of Chlorella spp. (Lee, 2001). These concrete ponds are commonly built with a depth of $25-30 \mathrm{~cm}$ and up to $45 \mathrm{~m}$ diameter while agitation is provided through a rotating arm. The algae are kept in suspension in $20-30 \mathrm{~cm}$ of nutrient-rich water with a paddlewheel. $\mathrm{CO}_{2}$ is bubbled into water to increase the total biomass yield due to the low solubility of atmospheric $\mathrm{CO}_{2}$ by the water.

\section{Closed Systems}

Many of the problems associated with open-pond systems can be reduced or eliminated in closed pond systems, also known as bioreactors. The minimization of water evaporation and reduction of contaminating species are the main advantages of closed systems. While the problem of contaminating species is substantially reduced, photobioreactors cannot totally prevent the presence of other algal strains within the dominant population (Tredici, 2004). Though photobioreactor algal biomass production could be significantly improved, the major limiting factors for commercialization of closed systems are high capital and O\&M costs.
Thus far, various types of photobioreactors have been designed for algae production.

\section{Tubular Photobioreactor}

Tubular photobioreactors, are the only type of closed systems which are employed for industrial purposes (Chisti, 2007). Common designs of vertical, horizontal, and helical tubular reactors are considered the easiest to scale up (Carvalho et al., 2006). In a common tubular photobioreactor, the algae and growth media are continuously circulated through the tubes to a reservoir using an airlift or mechanical pump (Razzak et al., 2013).

Pilot-scale tubular photobioreactors have been largely employed for growing a wide range of algae including Arthrospira, Porphyridium, Chlorella, Dunaliella, Haematococcus, Tetraselmis, and Phaeodactylum (Abdel-Raouf et al., 2012). Tubular photobioreactors have recurring problems including high levels of dissolved oxygen (DO) (Torzillo et al., 1986; Richmond et al., 1993; Molina et al., 2001), adverse $\mathrm{pH}$ and $\mathrm{CO}_{2}$ gradients. In addition, photoinhibition, especially when dealing with large scale applications, is a natural phenomenon occurring in outdoor photobioreactors (Vonshak and Torzillo, 2004).

\section{Flat Plate Photobioreactor}

The high degree of solar light on the surface of the plate, the lowered accumulation of dissolved oxygen and the convenience of modular design for scale-up are qualities that make flat-plate photobioreactors ideal for large-scale production in indoor and outdoor facilities. The drawbacks of flat plate photobioreactors include the ability to control the temperature, the formation of algal biofilms on the plates and the potential for hydrodynamic stress that could have a severe impact on certain strains of microalgae (Richmond and Cheng-Wu, 2001; Xu et al., 2009).

\section{Plastic Bag Photobioreactor}

Large bags nearly 0.5 meters in diameter and fitted with aerators are used as photobioreactors where they are hung vertically or placed in a metal or plastic cage for support and exposed to direct sunlight (Borowitzka, 1999; Tredici, 2004). In this system, the algae cultures are continuously mixed with diffused air pumped to the bottom of the bags (Tredici, 2004). The maintenance of this system demands frequent attention and the algae culture often crashes due to poor mixing.

\section{HARVESTING AND BIOMASS EXTRACTION}

Usually about 20 to $30 \%$ of the total production expenses for microalgae production is related to harvesting the biomass (Harun et al., 2011). The main problems in harvesting are the low biomass concentration in the open-pond cultivation system and the small cell size that makes the separation process consume a great deal of energy. Common methods of harvesting microalgae biomass include: coagulation, flocculation (or sedimentation), flotation (Harun et al., 2011),centrifugation (Molina Grima et al., 
2003), membrane filtration (Lourenco et al., 2002; Feofilova et al., 2010), and ultrasonic separation (Bosma et al., 2003).

Through the coagulation and flocculation processes, polymers or salts are added to the culture to efficiently concentrate dispersed microalgae cells into larger aggregates such that they can be more easily removed from the open ponds by skimming or flotation. The disadvantage of this method is extra expense due to additional purification needed because coagulants are usually not desired in the subsequent lipid extraction step for biofuel production. Centrifugation is regarded as the most efficient method to harvest the biomass using mechanical forces, but their application in large-scale is limited because of the energy costs. Centrifugation can be cost-effective but it requires a two-step process. The typical concentration of algae in open pond cultivation is approximately $300 \mathrm{mg} / \mathrm{L}$. Continuous-flow centrifuges work best if the source water has at least $1-3 \%$ solids. Gravity settling or dissolved air floatation are two simple methods to achieve the desired solids concentration. Membrane filtration has been applied in wastewater treatment involving removal of microalgae cell, which suffers some problems such as bio-fouling and also it is not cost-effective for large-scale biofuel production. Recently, ultrasonic separation (Varfolomeev et al., 2010) and electro-coagulation-flocculation (Vandamme et al., 2011) have been exploited for microalgae harvesting. Promising laboratoryscale results show that these methods are effective and have lowpower consumption comparing to centrifugation, but full-scale testing is still in needed to evaluate their cost and performance. After harvesting, the next major challenge is the de-watering the concentrated biomass. Usually, $90 \%$ of the post-harvest weight of the microalgae paste is water which needs to be reduced below $50 \%$ by weight for efficient oil extraction (Reijnders, 2008). Water is removed by heating the biomass that could consume a great amount of energy. However, this process often uses waste heat from power plants to reduce the cost. It is crucial to minimize water contents after harvesting process to decrease energy demand and increase downstream extraction and fuel conversion efficiency.

\section{THE POTENTIAL OF MICROALGAE IN WASTEWATER TREATMENT}

As a consequence of the world's growing population, the increase of urban wastewater production has become one of many environmental challenges. Urban effluents have to be welltreated to an environmentally safe level before discharge into rivers, lakes, or the oceans (Arbib et al., 2012). Wastewater treatment may be processed at primary, secondary or tertiary levels using physical, biological, or chemical processes. Primary treatment removes settleable solids that can cause operational problems in advanced treatment steps. Secondary treatment is a physical/biological process that consumes the dissolved organic matter and oxidizes the major nutrients to nitrate and orthophosphate. Tertiary is an advanced treatment process that removes nitrates, phosphates and trace organic compounds (Droste, 1997).

In the urban wastewater treatment, the removal of macronutrients such as nitrates and phosphates is one of the main criteria for tertiary treatment. Usually, nitrogen is removed without further recycling and thus it is converted to $\mathrm{N}_{2}$ and will pass into the atmosphere (George et al., 2003; Muylaert et al., 2015). Phosphorus is mainly precipitated by the addition of cations such as calcium, aluminum, and iron which is costly (George et al., 2003). As an alternative to conventional tertiary treatment, both nitrogen and phosphorus can be removed by rapidly growing cultures of algae. This way, nitrogen and phosphorus can directly be taken up by microalgae, resulting in valuable algal biomass. The biomass can further be utilized as biofuel, feedstock or agricultural fertilizer. Composting the algal biomass with green waste (leaves, grass, husks, etc.) for 6 months will be sufficient to remove the pathogens found in wastewater.

\section{Use of Microalgae Strains With Special Attributes}

Many species of microalgae are able to effectively remove nitrogen, phosphorus, heavy metals, pesticides, organic and inorganic toxins, and pathogens from wastewater. The main mechanism to remove pollutants includes accumulating and/or using them in their cells (Hoffmann, 1998). A number of studies have reported successful cultivation of several species of microalgae such as Chlorella, Scenedesmus, Phormidium, Botryococcus, Chlamydomonas, and Arthrospira for wastewater treatment and the efficacy of this method is promising (Olguì, 2003; Chinnasamy et al., 2010; Kong et al., 2010; Stephens et al., 2010; Pittman et al., 2011).

It should be noted that the efficiency of heavy metals removal depends on algal species. For example, chromium by Oscillatoria spp., cadmium, copper and zinc by Chlorella vulgaris, lead by Chlamydomonas spp., and molybdenum by Scenedesmus chlorelloides (Filip et al., 1979; Hassett et al., 1981; Sakaguchi et al., 1981; Ting et al., 1991). Furthermore, tolerance to organic pollutants in wastewater varies from species to species. Euglena, Oscillatoria, Chlamydomonas, Scenedesmus, Chlorella, Nitzschia, Navicula, and Stigeoclonium have been described as the most resistant genera to organic pollutants (Palmer, 1969).

\section{Systems of Algae-Based Waste Water Treatment}

The two forms of algae culturing systems most commonly used for wastewater treatment are HRAP and waste stabilization ponds (WSPs). These are large shallow-water basins often used in temperate and tropical climates. A WSP is similar to a conventional oxidation pond where the raw wastewater is treated by a combination of algal and bacterial processes. The bacteria break down the complex organic matter into simpler compounds and the algae provide the oxygen necessary to run the aerobic bacterial processes. In conventional oxidation ponds, mechanical aerators provide the oxygen. The substitution of photosynthesis in place of electromechanical processes make WSPs a costeffective, easily operated system for treating domestic and industrial effluent. This is especially significant with regards to wastewater treatment in tropical countries that often do not have a continuous supply of electricity.

Biochemical Oxygen Demand (BOD) is removed in the aerobic and anaerobic ponds in a WSP system. In the aerobic ponds, the algae produce oxygen that is used by the aerobic 
bacteria for the breakdown of complex organic matter. The residual $\mathrm{BOD}$ is removed in the anaerobic pond by heterotrophic bacteria including denitrifying bacteria. A final maturation pond plays a crucial role in the removal of human pathogens.

A low-cost approach to wastewater treatment and algae biomass production uses the HRAP system. This contains both a photobioreactor and intensified oxidation ponds where microalgae provide oxygen for bacteria, and in turn, bacteria convert mineral compounds (e.g., ammonium to nitrate) that supply nutrients for microalgae. This system is effective in reducing bacteria and BOD. Species of the genera Oscillatoria, Micractinium, Arthrospira, and Scenedesmus have been shown to grow well in HRAP systems and are relatively easy to harvest compared to smaller single-cell algae such as Chlorella spp. and Oocystis spp.

In traditional domestic wastewater, the ratios of carbon to nitrogen to phosphorus (C:N:P) are 20:8:1 while the C:N:P ratios for algae are 50:8:1. The additional carbon needed for algal photosynthesis is supplied from free carbon dioxide, which is the major limiting factor in HRAPs. Although high concentration of $\mathrm{CO}_{2}$ is generated by the bacteria in the ponds, a high photosynthetic rate can create a $\mathrm{CO}_{2}$ deficit. It is estimated that $30 \%$ of the total carbon required by microalgae can be supplied by sparging $\mathrm{CO}_{2}$ in these ponds (Craggs et al., 2013).

\section{THE INTEGRATION OF WASTEWATER TREATMENT TO CARBON CAPTURE TECHNOLOGY}

\section{Concept of Integration}

A proper medium for microalgae is supposed to provide sufficient nutrients that are needed for microalga growth. Wastewater combined with $\mathrm{CO}_{2}$ sparging creates an ideal growth medium for a wide variety of algae. However, in a domestic wastewater-based culturing system, the C:N ratio is not usually high enough to meet the requirements of algal biomass. In addition, atmospheric $\mathrm{CO}_{2}$ cannot sufficiently provide the needed carbon. Thus, the additional carbon could be supplied from other sources, such as flue gas (Larsson and Lindblom, 2011), which contains a high percentage of $\mathrm{CO}_{2}$ (Aaron and Tsouris, 2005). This $\mathrm{CO}_{2}$ addition can directly enhance the algal production that in turn can improve the efficiency of wastewater treatment. Previous publications have stated that the addition of $\mathrm{CO}_{2}$ to HRAP fed with domestic wastewater can remove nutrients to a level of treatment similar to those achieved by mechanical treatment technologies (Woertz et al., 2009). Furthermore, combining the wastewater nutrient removal with capturing $\mathrm{CO}_{2}$ from flue gas may provide an environmentally and economically useful system to reduce greenhouse gas emission. Numerous studies have demonstrated that wastewater grown algae has higher photosynthetic efficiencies and productivities when $\mathrm{CO}_{2}$ is added to the culture (FitzGerald and Rohlich, 1964; Heubeck et al., 2007; Kuo et al., 2016; Chaudhary et al., 2018). Bush et al. (1961) concluded that maximum algal productivity couldn't be gained unless $\mathrm{CO}_{2}$ was bubbled into algae wastewater pond. An increase in $\mathrm{pH}$ due to photosynthetic activity in any cultivation system can inhibit the optimum growth of microalgae. Addition of $\mathrm{CO}_{2}$ to wastewater treatment HRAP systems makes a balance in the acidity of media and thus neutralizes the effect of increasing $\mathrm{pH}$. By sparging the system with $\mathrm{CO}_{2}$, the system can maintain an optimal $\mathrm{pH}$ in the range of 7.5-8.

\section{Energy Efficiency of Microalgae-Based Wastewater Treatment}

Wastewater can potentially be converted into fertilizer. Unfortunately, a significant amount of these potential fertilizers is lost as untreated or partially treated wastewater worldwide. Synthetic agricultural fertilizers such as urea, di-ammonium phosphate, and potash are estimated to worth $\$ 420, \$ 480$, and $\$ 400$ per ton, respectively (Komolafe et al., 2014). An added benefit of algae-based fertilizer is its ability to retain moisture in the soil and there is a slow release of $\mathrm{N}$ and $\mathrm{P}$ over time as needed by the terrestrial plants and trees. Thus, the ability of microalgae growing in wastewater to convert pollutants to a valuable biomass is of economic importance. In contrast, traditional wastewater treatment methods are dependent on the high cost of energy and treatment chemicals.

For example, aerobic decomposition of dissolved and particulate organic matter by bacteria in the sewage needs a high amount of oxygen. The energy input in the mechanical approaches is also high $(45-75 \%$ of total energy costs). In addition, the process of nitrification added to an activated sludge wastewater treatment plant would increase the amount of energy by $60-80 \%$ (Maurer et al., 2003). The nutrient uptake rates for nitrogen in microalgae-based wastewater treatment systems can reach $24 \mathrm{~kg} \mathrm{~N} /$ ha/day and $3 \mathrm{~kg} \mathrm{P} / \mathrm{ha} /$ day. This is based on an assumed productivity of $30 \mathrm{~g} / \mathrm{m}^{2} /$ day algal biomass (dry weight). Overall the CC and O\&M costs for an algae-based wastewater treatment system are far lower than comparable costs using conventional mechanical and chemical treatment technologies.

In addition to the afore-mentioned economical merits, treating wastewater with microalgae is essential for capturing $\mathrm{CO}_{2}$. A microalgae-based $\mathrm{CO}_{2}$ bio fixation requires a cost efficient system (i.e., HRAPs) and a low-cost nutrients source (i.e., wastewater). This suggests that $\mathrm{CO}_{2}$ removal could occur in both photobioreactors and HRAPs, making a synergistic integration (de Godos et al., 2010). A HRAP system using sunlight, bacteria and photosynthesis compared to the electromechanical treatment in a conventional oxidation pond reduces 100 to 200 tons of $\mathrm{CO}_{2}$ per ML of treated wastewater (Green et al., 1995; Benemann and Pedroni, 2003). An additional 100 to 200 tons of $\mathrm{CO}_{2}$ per ML could be abated due to the algal assimilation of nitrogen (Shilton, 2005).

\section{The Role of Integration in Reducing Fertilizer-Caused $\mathrm{CO}_{2}$ Emission}

Typically, the production of one ton of nitrogen and phosphate fertilizers will release 3.15 and 1.39 tone $\mathrm{CO}_{2 \mathrm{EQV}}$, respectively (West and Marland, 2002; Wood and Cowie, 2004). One kg of algae containing $7 \% \mathrm{~N}$ and $0.8 \% \mathrm{P}$ used as a fertilizer has the potential to reduce the $\mathrm{CO}_{2}$ emissions from conventional inorganic fertilizers by $0.23 \mathrm{~kg} \mathrm{CO}_{2 \mathrm{EQV} \mathrm{kg}} \mathrm{kg}^{-1}$ Algae (West and Marland, 2002; Wood and Cowie, 2004). 


\section{Use of the Integration Systems in Biofuel Generation}

HRAP-based wastewater treatment is currently the most economical and environmental approach to produce algal biomass for conversion to biofuels. In this regard, technologies have been developed to raise the efficiency of microalgal $\mathrm{CO}_{2}$ fixation integrated with wastewater treatment, leading to value added products such biofuels (Kumar et al., 2010). By producing one ton algal biomass in HRAP-based wastewater treatment approximately 1.8 tons of $\mathrm{CO}_{2}$ can be fixed through photosynthesis (Benemann and Pedroni, 2003). Once converted to biofuel, this offsets emitted $\mathrm{CO}_{2}$ from the combustion of fossil fuel. For example, generating electricity from biogas methane accounts for mitigating $\mathrm{CO}_{2}$ emission to the atmosphere at $0.4 \mathrm{~kg}$ $\mathrm{CO}_{2 \mathrm{EQV}} \mathrm{kWh}^{-1}$ and $1.0 \mathrm{~kg} \mathrm{CO}_{2 \mathrm{EQV}} \mathrm{kWh}^{-1}$ in comparison with natural gas and coal electricity generation. The use of algae-based biodiesel and bio-crude oil in place of petroleum-based diesel and heavy bunker fuel will result in a change in Green House Gas emission abatement of $2.68 \mathrm{~kg} \mathrm{CO}_{2 \mathrm{EQV} \mathrm{L}} \mathrm{L}^{-1}$ and $2.99 \mathrm{~kg} \mathrm{CO}_{2 \mathrm{EQV} \mathrm{L}} \mathrm{L}^{-1}$, respectively (New Zealand Ministry of Economic Development, 2007).

\section{INHERENT CHALLENGES ASSOCIATED WITH SCALE UP}

Heavy metal ions such as $\mathrm{Cd}, \mathrm{Cr}, \mathrm{Zn}$, and other ions, as well as organic chemical toxins such as surfactants, hydrocarbons, and biocides are all present in industrial wastewaters (Ahluwalia and Goyal, 2007). Effluents from metal processing industries as well as textile, leather, tannery, electroplating, and other industries have varying amounts of toxic metal ions. Because of low concentrations of $\mathrm{N}$ and $\mathrm{P}$ containing compounds as well as high levels of toxins, algal growth rates are lower in different industrial wastewaters as compared to those of domestic wastewater. Therefore, there is less potential for the large scale treatments of industrial wastewaters containing high levels of heavy metal ions for algal culture concurrent with $\mathrm{CO}_{2}$ removal. When the industrial wastewaters contain moderate levels of heavy metal ions, as well as $\mathrm{P}$ and $\mathrm{N}$ containing compounds at low concentrations they would be able to support algal growth. As previously mentioned, certain microalgal species are able to remove various types of metal ions. The main challenges that remain to be addressed by the researchers include but not limited to: industrial-scale capturing of carbon dioxide using microalgal species, the tolerances of specific algal strains grown in a wide variety and

\section{REFERENCES}

Aaron, D., and Tsouris, C. (2005). Separation of $\mathrm{CO}_{2}$ from flue gas: a review. Separ. Sci. Technol. 40, 321-348. doi: 10.1081/SS-2000 42244

Abdel-Raouf, N., Al-Homaidan, A. A., and Ibraheem, I. B. (2012). Microalgae and wastewater treatment. Saudi J. Biol. Sci. 19, 257-275. doi: $10.1016 /$ j.sjbs.2012.04.005 concentration of heavy metal ions in industrial wastewaters, and the numerous parameters to be optimized for simultaneous removal of $\mathrm{CO}_{2}$ and treatment of wastewaters containing heavy metal ions.

\section{CONCLUSION}

Microalgae cultivation is one of the most efficient approaches to remove $\mathrm{CO}_{2}$ and each cultivation system has its advantage and drawbacks. Thus, selection of the best strategy strongly depends on the purpose, scale, microalgae species, and cost. However, open ponds appear to be more economically feasible than photobioreactors. In addition to $\mathrm{CO}_{2}$-biofixation, microalgae have been shown to be highly efficient in wastewater treatment. HRAP can provide efficient tertiary-level wastewater treatment compared to electromechanical wastewater treatment technologies and at a far lower cost. While it is possible to separately use microalgae for any of the processes of $\mathrm{CO}_{2}$ biofixation, wastewater treatment, or biofuel production, it would be more efficient to integrate all of these processes. Integration of microalgae-based $\mathrm{CO}_{2}$ fixation, biofuel production, and wastewater treatment could be considered multi-faceted approaches to manage important environmental challenges. It is a green and sustainable tool for reducing the production costs of bio-diesel, agricultural fertilizers, wastewater treatment, and flue gas treatment. Finally, it may lead to a reduction in greenhouse gases in an efficient way. In the future, large-scale algae-based treatment programs could minimize the current technical/economic barriers of microalgae-based bio-fuel production.

\section{DATA AVAILABILITY}

All datasets generated for this study are included in the manuscript and/or the supplementary files.

\section{AUTHOR CONTRIBUTIONS}

This work is part of the M.Sc. thesis that MM did under the supervision of HA. HP and SL were involved in advising MM during her M.Sc. period. PR also read the manuscript several times and provided very detailed comments to improve the quality of the selected materials.

\section{ACKNOWLEDGMENTS}

HA thanks Ferdowsi University of Mashhad for financial support.

Ahluwalia, S. S., and Goyal, D. (2007). Microbial and plant derived biomass for removal of heavy metals from wastewater. Bioresour. Technol. 98:2243. doi: 10.1016/j.biortech.2005.12.006

Allen, J., and Brent, G. F. (2010). Sequestering $\mathrm{CO}_{2}$ by mineral carbonation: stability against acid rain exposure. Environ. Sci. Technol. 44, 2735-2739. doi: $10.1021 /$ es903212j

Arbib, Z., Ruiz, J., Alvarez, P., Garrido, C., Barragan, J., and Perales, J. A. (2012). Chlorella stigmatophora for urban wastewater nutrient removal and 
$\mathrm{CO}_{2}$ abatement. Int. J. Phytoremed. 14, 714-725. doi: 10.1080/15226514. 2011.619237

Becker, E. (2007). Micro-algae as a source of protein. Biotechnol. Adv. 25, 207-210. doi: 10.1016/j.biotechadv.2006.11.002

Becker, E. W. (1994). Microalgae: Biotechnology and Microbiology. Cambridge University Press.

Benemann, J. R., Tillett, D. M., and Weissman, J. C. (1987). Microalgae biotechnology. Trends Biotechnol. 5, 47-53. doi: 10.1016/0167-7799(87)90037-0

Benemann, M. A., and Pedroni, P. M. (2003). Biofixation of $\mathrm{CO}_{2}$ and Greenhouse Gas Abatement With Microalgae. Final Report Prepared for US DOE.

Bilanovic, D., Andargatchew, A., Kroeger, T., and Shelef, G. (2009). Freshwater and marine microalgae sequestering of $\mathrm{CO}_{2}$ at different $\mathrm{C}$ and $\mathrm{N}$ concentrations-response surface methodology analysis. Energy Convers. Manage. 50, 262-267. doi: 10.1016/j.enconman.2008. 09.024

Borowitzka, L. J., and Borowitzka, M. A. (1990). Commercial production of $\beta$-carotene by Dunaliella salina in open ponds. Bull. Mar. Sci. 47, 244-252.

Borowitzka, M. A. (1999). Commercial production of microalgae: ponds, tanks, tubes and fermenters. J. Biotechnol. 70, 313-321. doi: 10.1016/S0168-1656(99)00083-8

Bosma, R., van Spronsen, W. A., Tramper, J., and Wijffels, R. H. (2003). Ultrasound, a new separation technique to harvest microalgae. J. Appl. Phycol. 15, 143-153. doi: 10.1023/A:1023807011027

Brune, D. E., Collier, J. A., Schwedler, T. E., and Eversole, A. G. (2007). Controlled Eutrophication System and Process. United States patent US 7258790 .

Bush, F., Isherwood, J. D., and Rodgi, S. (1961). Dissolved solids removal from waste water by algae. J. Sanitary Eng. Div. 87, 39-60.

Cai, T., Park, S. Y., and Li, Y. (2013). Nutrient recovery from wastewater streams by microalgae: status and prospects. Renewable Sustain. Energy Rev. 19, 360-369. doi: 10.1016/j.rser.2012.11.030

Carvalho, A. P., Meireles, L. A., and Malcata, F. X. (2006). Microalgal reactors: a review of enclosed system designs and performances. Biotechnol. Prog. 22, 1490-1506. doi: 10.1002/bp060065r

Celia, M. A., Nordbotten, J. M., Bachu, S., Dobossy, M., and Court, B. (2009). Risk of leakage versus depth of injection in geological storage. Energy Procedia 1, 2573-2580. doi: 10.1016/j.egypro.2009.02.022

Chaudhary, R., Dikshit, A. K., and Tong, Y. W. (2018). Carbon-dioxide biofixation and phycoremediation of municipal wastewater using Chlorella vulgaris and Scenedesmus obliquus. Environ. Sci. Pollut. Res. Int. 25, 20399-20406. doi: 10.1007/s11356-017-9575-3

Chaumont, D. (1993). Biotechnology of algal biomass production: a review of systems for outdoor mass culture. J. Appl. Phycol. 5, 593-604. doi: 10.1007/BF02184638

Cheah, W. Y., Show, P. L., Chang, J.-S., Ling, T. C., and Juan, J. C. (2015). Biosequestration of atmospheric $\mathrm{CO}_{2}$ and flue gascontaining $\mathrm{CO}_{2}$ by microalgae. Bioresour. Technol. 184, 190-201. doi: 10.1016/j.biortech.2014.11.026

Chinnasamy, S., Bhatnagar, A., Hunt, R. W., and Das, K. (2010). Microalgae cultivation in a wastewater dominated by carpet mill effluents for biofuel applications. Bioresour. Technol. 101, 3097-3105. doi: 10.1016/j.biortech.2009.12.026

Chisti, Y. (2007). Biodiesel from microalgae. Biotechnol. Adv. 25, 294-306. doi: 10.1016/j.biotechadv.2007.02.001

Collotta, M. P., Champagne, W. M., and Tomasoni, G. (2018). Wastewater and waste $\mathrm{CO}_{2}$ for sustainable biofuels from microalgae. Algal Res. 29, 12-21. doi: 10.1016/j.algal.2017.11.013

Coyle, W. A. (2007). Global Perspective: The Future of Biofuels.Service. Washington, and AmberWaves/November07/PDF/Biofuels.pdf

Craggs, R. J., Lundquist, T. J., and Benemann, J. R. (2013). "Wastewater treatment and algal biofuel production," in Algae for Biofuels and Energy, eds M. A. Borowitzka and N. R. Moheimani (Murdoch, WA: Murdoch University Australia, Springer), 153-163.

de Godos, I.,Blanco, S., García-Encina, P. A., Becares, E., and Muñoz, R. (2010). Influence of flue gas sparging on the performance of high rate algae ponds treating agro-industrial wastewaters. J. Hazardous Mat. 179, 1049-1054. doi: 10.1016/j.jhazmat.2010.03.112
Demirbas, A. (2011). Biodiesel from oilgae, biofixation of carbon dioxide by microalgae: a solution to pollution problems. Appl. Energy 88, 3541-3547. doi: 10.1016/j.apenergy.2010.12.050

Desideri, U., and Corbelli, R. (1998). $\mathrm{CO}_{2}$ capture in small size cogeneration plants: technical and economical considerations. Energy Convers. Manage. 39, 857-867. doi: 10.1016/S0196-8904(97)10050-4

Droste, R. L. (1997). Theory and Practice of Water and Wastewater Treatment. New York, NY: John Wiley and Sons.

Dvir, I., Stark, A. H., Chayoth, R., Madar, Z., and Arad, S. M. (2009). Hypocholesterolemic effects of nutraceuticals produced from the red microalga Porphyridium sp. in rats. Nutrients 1, 156-167. doi: 10.3390/nu1020156

E. I. A. U.S. Department of Energy (1997). Emissions of Greenhouses Gases in the United States 1996, DOE/EIA-0573(96).

Erga, O., Juliussen, O., and Lidal, H. (1995). Carbon dioxide recovery by means of aqueous amines. Energy Convers. Manage. 36, 387-392. doi: 10.1016/0196-8904(95)00027-B

Fang, S.-C., Poon, Y., and Mendez, M. (2010). Genetically Engineered Herbicide Resistant Algae. Patent cooperation treaty application WO 2010078156.

Feofilova, E. P., Sergeeva, Y. E., and Ivashechkin, A. (2010). Biodiesel-fuel: content, production, producers, contemporary biotechnology (Review). Appl. Biochem. Microbiol. 46, 369-378. doi: 10.1134/S0003683810040010

Filip, D. S., Peters, V. T., Adams, E. D., and Middlebrooks, J. (1979). Residual heavy metal removal by an algae-intermittent sand filtration system. Water Res. 13, 305-313. doi: 10.1016/0043-1354(79)90211-2

FitzGerald, G., and Rohlich, G. A. (1964). Biological removal of nutrients from treated sewage: laboratory experiments. SIL Proc. 15, 597-608. doi: 10.1080/03680770.1962.11895577

George, T., Franklin, L., and Stensel, H. D. (2003). Wastewater Engineering: Treatment and Reuse. New York, NY: Metcalf and Eddy, Inc.

Green, B., Lundquist, T., and Oswald, W. (1995). Energetics of advanced integrated wastewater pond systems. Water Sci. Technol. 31, 9-20. doi: 10.2166/wst.1995.0448

Gressler, V., Yokoya, N. S., Fujii, M., T., Colepicolo, P., Mancini Filho, J., Torres, R. P., et al.. (2010). Lipid, fatty acid, protein, amino acid and ash contents in four Brazilian red algae species. Food Chem. 120, 585-590. doi: 10.1016/j.foodchem.2009.10.028

Hanagata, N., Takeuchi, T., Fukuju, Y., Barnes, D. J., and Karube, I. (1992). Tolerance of microalgae to high $\mathrm{CO}_{2}$ and high temperature. Phytochemistry 31, 3345-3348. doi: 10.1016/0031-9422(92)83682-O

Hanin, M., Ebel, C., Ngom, M., Laplaze, L., and Masmoudi, K. (2010). Engineering Salt Tolerance in Photosynthetic Microorganisms. Patent Cooperation Treaty Application WO 2010105095.

Harun, R., Davidson, M., Doyle, M., Gopiraj, R., Danquah, M., and Forde, G. (2011). Technoeconomic analysis of an integrated microalgae photobioreactor, biodiesel and biogas production facility. Biomass Bioener. 35, 741-747. doi: 10.1016/j.biombioe.2010.10.007

Hassett, J. M., Jennett, J. C., and Smith, J. E. (1981). Microplate technique for determining accumulation of metals by algae. Appl. Environ. Microbiol. 41, 1097-1106.

He, P., Zeng, Y., Du, D., Lin, Y.-J., Wang, Y., and Abdel-Fattah A. (2016). A review of novel materials and technologies for the sustainable development of microalgae biofuel.

Herzog, H., and Golomb, D. (2004). Carbon capture and storage from fossil fuel use. Encycl. Energy 1, 1-11. doi: 10.1016/B0-12-176480-X/00422-8

Heubeck, S., Craggs, R. J., and Shilton, A. (2007). Influence of $\mathrm{CO}_{2}$ scrubbing from biogas on the treatment performance of a high rate algal pond. Water Sci. Technol. 55, 193-200. doi: 10.2166/wst.2007.358

Hoffmann, J. P. (1998). Wastewater treatment with suspended and nonsuspended algae. J. Phycol. 34, 757-763. doi: 10.1046/j.1529-8817.1998.340757.x

Iasimone, F., De Felice, V., Panico, A., and Pirozzi, F. (2017). Experimental study for the reduction of $\mathrm{CO}_{2}$ emissions in wastewater treatment plant using microalgal cultivation. J. $\mathrm{CO}_{2}$ Utiliz. 22, 1-8. doi: 10.1016/j.jcou.2017. 09.004

Jiang, Y., Zhang, W., Wang, J., Chen, Y., Shen, S., and Liu, T. (2013). Utilization of simulated flue gas for cultivation of Scenedesmus dimorphus. Bioresour. Technol. 128, 359-364. doi: 10.1016/j.biortech.2012.10.119

Kao, C.-Y., Chen, T.-Y., Chang, Y.-B., Chiu, T.-W., Lin, H.-Y., Chen, C.D., et al. (2014). Utilization of carbon dioxide in industrial flue gases for 
the cultivation of microalga Chlorella sp. Bioresour. Technol. 166, 485-493. doi: 10.1016/j.biortech.2014.05.094

Khoo, H. H., and Tan, R. B. (2006). Life cycle investigation of $\mathrm{CO}_{2}$ recovery and sequestration. Environ. Sci. Technol. 40, 4016-4024. doi: 10.1021/es051882a

Komolafe, O., Velasquez Orta, S. B., Monje-Ramirez, I., Yáñez Noguez, I., Harvey, A. P., and Orta Ledesma, M. T. (2014). Biodiesel production from indigenous microalgae grown in wastewater. Bioresour. Technol. 154, 297-304. doi: 10.1016/j.biortech.2013.12.048

Kong, Q.-X., Li, L., Martinez, B., Chen, P., and Ruan, R. (2010). Culture of microalgae Chlamydomonas reinhardtii in wastewater for biomass feedstock production. Appl. Biochem. Biotechnol. 160, 9-18. doi: 10.1007/s12010-009-8670-4

Kumar, A., Ergas, S., Yuan, X., Sahu, A., Zhang, Q., Dewulf, J., et al. (2010). Enhanced $\mathrm{CO}_{2}$ fixation and biofuel production via microalgae: recent developments and future directions. Trends Biotechnol. 28, 371-380. doi: 10.1016/j.tibtech.2010.04.004

Kuo, C. M., Jian, J. F., Lin, T. H., Chang, Y. B., Wan, X. H., Lai, J. T., et al. (2016). Simultaneous microalgal biomass production and $\mathrm{CO}_{2}$ fixation by cultivating Chlorella sp. GD with aquaculture wastewater and boiler flue gas. Bioresour. Technol. 221, 241-250. doi: 10.1016/j.biortech.2016.09.014

Lackner, K. S. (2003). Climate change: a guide to $\mathrm{CO}_{2}$ sequestration. Science 300, 1677-1678. doi: 10.1126/science.1079033

Lackner, K. S., and Brennan, S. (2009). Envisioning carbon capture and storage: expanded possibilities due to air capture, leakage insurance, and C-14 monitoring. Clim. Change 96, 357-378. doi: 10.1007/s10584-009-9632-0

Larsson, M., and Lindblom, J. (2011). Algal Flue Gas Sequestration and Wastewater Treatment: An Industrial Experiment. Master's Thesis, KTH Industrial Engineering and Management Machine Design.

Lee, Y.- K. (1997). Commercial production of microalgae in the Asia-Pacific rim. J. Appl. Phycol. 9, 403-411. doi: 10.1023/A:1007900423275

Lee, Y.-K. (2001). Microalgal mass culture systems and methods: their limitation and potential. J. Appl. Phycol. 13, 307-315. doi: 10.1023/A:1017560006941

Li, F.-F., Yang, Z.-H., Zeng, R., Yang, G., Chang, X. J.,Yan, B., et al. (2011). Microalgae capture of $\mathrm{CO}_{2}$ from actual flue gas discharged from a combustion chamber. Indust. Eng. Chem. Res. 50, 6496-6502. doi: 10.1021/ie200040q

Lizzul, A. M., Hellier, P., Purton, S., Baganz, F., Ladommatos, N., and Campos, L. (2014). Combined remediation and lipid production using Chlorella sorokiniana grown on wastewater and exhaust gases. Bioresour. Technol. 151, 12-18. doi: 10.1016/j.biortech.2013.10.040

Lourenco, S. O., Barbarino, E., Mancini-Filho, J., Schinke, K. P., and Aidar, E. (2002). Effects of different nitrogen sources on the growth and biochemical profile of 10 marine microalgae in batch culture: an evaluation for aquaculture. Phycologia 41, 158-168. doi: 10.2216/i0031-8884-412-158.1

Mata, T. M., Martins, A. A., and Caetano, N. S. (2010). Microalgae for biodiesel production and other applications: a review. Renew. Sustain. Energy Rev. 14, 217-232. doi: 10.1016/j.rser.2009.07.020

Maurer, M., Schwegler, P., and Larsen, T. A. (2003). Nutrients in urine: energetic aspects of removal and recovery. Water Sci. Technol. 48, 37-46. doi: 10.2166/wst.2003.0011

Meisen, A., and Shuai, X. (1997). Research and development issues in CO2 capture. Energy Convers. Manage. 38, S37-S42. doi: 10.1016/S0196-8904(96)00242-7

Mendez, M., Craig, B., Poon, Y., and Lee, P. (2009a). Induction of Flocculation in Photosynthetic Organisms. Patent cooperation treaty application WO 2009158658.

Mendez, M., O'neill, B., and Mikkelson, K. (2009b). System for Capturing and Modifying Large Pieces of Genomic DNA and Constructing Organisms With Synthetic Chloroplasts.

Mendez, M., O’neill, Burkart, M., Behnke, C., Lieberman, S., Bielinski, V., et al. (2010). Production of Fatty Acids by Genetically Modified Photosynthetic Microorganisms.

Moheimani, N. R., and Borowitzka, M. A. (2006). The long-term culture of the coccolithophore Pleurochrysis carterae (Haptophyta) in outdoor raceway ponds. J. Appl. Phycol. 18, 703-712. doi: 10.1007/s10811-006-9075-1

Molina Grima, E., Belarbi, E.-H., AciénvFernández, F. G., Robles Medina, A., and Chisti, Y. (2003). Recovery of microalgal biomass and metabolites: process options and economics. Biotechnol. Adv. 20, 491-515. doi: 10.1016/S0734-9750(02)00050-2
Molina, E., Fernández, J., Acién, F. G., and Chisti, Y. (2001). Tubular photobioreactor design for algal cultures. J. Biotechnol. 92, 113-131. doi: 10.1016/S0168-1656(01)00353-4

Muylaert, K., Beuckels, A., Depraetere, O., Foubert, I., Markou, G., and Vandamme, D. (2015). "Wastewater as a source of nutrients for microalgae biomass production," in Biomass Biofuels from Microalgae (Springer), 75-94.

New Zealand Ministry of Economic Development (2007). New Zealand Energy Greenhouse Gas Emissions 1990-2006. Report. Wellington: New Zealand Ministry of Economic Development.

Olgui, E. J. (2003). Phycoremediation: key issues for cost-effective nutrient removal processes. Biotechnol. Adv. 22, 81-91. doi: 10.1016/S0734-9750(03)00130-7

Pachauri, R., and Reisinger, A. (2007). IPCC Fourth Assessment Report. Geneva: IPCC.

Palmer, C. M. (1969). A composite rating of algae tolerating organic pollution. J. Phycol. 5, 78-82. doi: 10.1111/j.1529-8817.1969.tb02581.x

Pires, J. C. M., Martins, F. G., Alvim-Ferraz, M. C. M., and Simões, M. (2011). Recent developments on carbon capture and storage: An overview. Chem. Eng. Res. Des. 89, 1446-1460. doi: 10.1016/j.cherd.2011.01.028

Pittman, J. K., Dean, A. P., and Osundeko, O. (2011). The potential of sustainable algal biofuel production using wastewater resources. Bioresour. Technol. 102, 17-25. doi: 10.1016/j.biortech.2010.06.035

Plaza, M., Cifuentes, A., and Ibáñez, E. (2008). In the search of new functional food ingredients from algae. Trends Food Sci. Technol. 19, 31-39. doi: 10.1016/j.tifs.2007.07.012

Raja, R., Hemaiswarya, S., Kumar, N. A., Sridhar, S., and Rengasamy, R. (2008). A perspective on the biotechnological potential of microalgae. Crit. Rev. Microbiol. 34, 77-88. doi: 10.1080/10408410802086783

Razzak, S. A., Hossain, M. M., Lucky, R. A., Bassi, A. S., and de Lasa, H. (2013). Integrated $\mathrm{CO}_{2}$ capture, wastewater treatment and biofuel production by microalgae culturing-a review. Renew. Sustain. Energy Rev. 27, 622-653. doi: 10.1016/j.rser.2013.05.063

Reijnders, L. (2008). Do biofuels from microalgae beat biofuels from terrestrial plants? Trends Biotechnol. 26, 349-350. doi: 10.1016/j.tibtech.2008.04.001

Richmond, A., and Cheng-Wu, Z. (2001). Optimization of a flat plate glass reactor for mass production of Nannochloropsis sp. outdoors. J. Biotechnol. 85, 259-269. doi: 10.1016/S0168-1656(00)00353-9

Richmond, B. S., Vonshak, A., and Kopel, R. (1993). A new tubular reactor for mass production of microalgae outdoors. J. Appl. Phycol. 5, 327-332. doi: 10.1007/BF02186235

Sabra, W., Zeng, A. P., and Deckwer, W.-D. (2001). Bacterial alginate: physiology, product quality and process aspects. Appl. Microbiol. Biotechnol. 56, 315-325. doi: $10.1007 /$ s002530100699

Sakaguchi, T., Nakajima, A., and Horikoshi, T. (1981). Studies on the accumulation of heavy metal elements in biological systems. Eur. J. Appl. Microbiol. Biotechnol. 12, 84-89. doi: 10.1007/BF01970039

Schwartz, M., M., G., and Van Olst, J., Carlberg, J. (2010). Method of Developing A Rapidly Settling Algal Floc. United States patent application US 20100264094 .

Sears, J. T. (2007). Method, and System for Biodiesel Production From Algae. United States patent application US 20070048848.

Shilton, A. (2005). Pond Treatment Technology. IWA Publishing.

Stephens, E., Ross, I. L., Mussgnug, J. H., Wagner, L. D., Borowitzka, M. A., Posten, C., et al. (2010). Future prospects of microalgal biofuel production systems. Trends Plant Sci. 15, 554-564. doi: 10.1016/j.tplants.2010.06.003

Stewart, C., and Hessami, M.-A. (2005). A study of methods of carbon dioxide capture and sequestration-the sustainability of a photosynthetic bioreactor approach. Energy Convers. Manage. 46, 403-420. doi: 10.1016/j.enconman.2004.03.009

Sung, K.-D., Lee, J.-S., Shin, C.-S., and Park, S.-C. (1998). Isolation of a new highly $\mathrm{CO}_{2}$ tolerant fresh water MicroalgaChlorella sp. KR-1. Kor. J. Chem. Eng. 15, 449-450. doi: 10.1007/BF02697138

Sydney, E. B., Sturm, W., de Carvalho, J. C., Thomaz-Soccol, V., and Larroche, C., Pandey, A., et al. (2010). Potential carbon dioxide fixation by industrially important microalgae. Bioresour. Technol. 101, 5892-5896 doi: 10.1016/j.biortech.2010.02.088

Thiruvenkatachari, R., Su, S., An, H., and Yu, X. X. (1997). Post combustion $\mathrm{CO}_{2}$ capture by carbon fibre monolithic adsorbents. Prog. Energy Combust. Sci. 35, 438-455. doi: 10.1016/j.pecs.2009.05.003 
Ting, Y. P., Prince, I. G., and Lawson, F. (1991). Uptake of cadmium and zinc by the alga Chlorella vulgaris: II. multi-ion situation. Biotechnol. Bioeng. 37, 445-455. doi: 10.1002/bit.260370506

Torzillo, G., Pushparaj, B., Bocci, F., Balloni, W., Materassi, R., and Florenzano, G. (1986). Production of spirulina biomass in closed photobioreactors. Biomass 11, 61-74. doi: 10.1016/0144-4565(86)90021-1

Tredici, M. R. (2004). "Mass production of microalgae: photobioreactors," in Handbook Microalgal Culture: Biotechnology and Applied Phycology, 178-214.

Ugwu, C. U., Aoyagi, H., and Uchiyama, H. (2008). Photobioreactors for mass cultivation of algae. Bioresour. Technol. 99, 4021-4028. doi: 10.1016/j.biortech.2007.01.046

Vandamme, D., Pontes, S. C., Goiris, K., Foubert, I., Pinoy, L. J., and Muylaert, K. (2011). Evaluation of electro-coagulation-flocculation for harvesting marine and freshwater microalgae. Biotechnol. Bioeng. 108, 2320-2329. doi: 10.1002/bit.23199

Varfolomeev, S. D., Efremenko, E. N., and Krylova, L. P. (2010). Biofuels. Russian Chem. Rev. 79, 491-509. doi: 10.1070/RC2010v079n06ABEH004138

Vonshak, A., and Torzillo, G. (2004). "Environmental stress physiology," in Handbook of Microalgal Culture: Biotechnology and Applied Phycology, Vol. 57, ed A. Richmond (Oxford: Blackwell Science, Wiley Online Library).

Wang, B., Lan, C. Q., and Horsman, M. (2012). Closed photobioreactors for production of microalgal biomasses. Biotechnol. Adv. 30, 904-912. doi: 10.1016/j.biotechadv.2012.01.019

West, T. O., and Marland, G. (2002). A synthesis of carbon sequestration, carbon emissions, and net carbon flux in agriculture: comparing tillage practices in the United States. Agric. Ecosyst. Environ. 91, 217-232. doi: 10.1016/S0167-8809(01)00233-X

Wilkerson, B. D., Chen, J. C., Pulse, J., Guschin, A., and Weaver, M. (2009). Systems, Devices, and Methods for Biomass Production. United States patent application US 20090047722.

Wilkerson, B. D., and Watters, W. (2009). Illumination Systems, Devices, and Methods for Biomass Production. United States patent application US 20090148931

Willson, B. D., Turner, C. W., Babbitt, G. R., Letvin, P. A., and Wickrmasinghe, S. R. (2009). Permeable Membranes in Film Photobioreactors. United States Patent Application US 20090305389.
Willson, G. B., Turner, C., Levtin, P., Weyer-Geigel, K., Ettinger, A., et al. (2008). Diffuse Light Extended Surface Area Water-Supported Photobioreactor. United States patent application US 20080160591.

Woertz, I., Feffer, A., Lundquist, T., and Nelson, Y. (2009). Algae grown on dairy and municipal wastewater for simultaneous nutrient removal and lipid production for biofuel feedstock. J. Environ. Eng. 135, 1115-1122. doi: 10.1061/(ASCE)EE.1943-7870.0000129

Wood, S., and Cowie, A. (2004). "A review of greenhouse gas emission factors for fertiliser production," in IEA Bioenergy Task (Harvard), 1-20.

Wu, B. C., Stephen, D., Morgenthaler, G. E., and Jones, D. V. (2010a). Systems and Methods for Producing Biofuels From Algae. United States patent application US 20100077654.

Wu, B. C., Stephen, D., Morgenthaler, G. E., and Jones, D. V. (2010b). Systems and Methods for Producing Biofuels From Algae. United States patent application US 20100081835

Xiao, P., Zhang, J., Webley, P., Li, G., Singh, R., and Todd, R. (2008). Capture of $\mathrm{CO}_{2}$ from flue gas streams with zeolite $13 \mathrm{X}$ by vacuum-pressure swing adsorption. Adsorption 14, 575-582. doi: 10.1007/s10450-008-9128-7

Xu, L., Weathers, P. J., Xiong, X. R., and Liu, C. Z. (2009). Microalgal bioreactors: challenges and opportunities. Eng. Life Sci. 9, 178-189. doi: 10.1002/elsc.200800111

Yamasaki, A. (2003). An overview of $\mathrm{CO}_{2}$ mitigation options for global warmingemphasizing $\mathrm{CO}_{2}$ sequestration options. J. Chem. Eng. Jpn. 36, 361-375. doi: $10.1252 /$ jcej.36.361

Conflict of Interest Statement: The authors declare that the research was conducted in the absence of any commercial or financial relationships that could be construed as a potential conflict of interest.

Copyright (C) 2019 Molazadeh, Ahmadzadeh, Pourianfar, Lyon and Rampelotto. This is an open-access article distributed under the terms of the Creative Commons Attribution License (CC BY). The use, distribution or reproduction in other forums is permitted, provided the original author(s) and the copyright owner(s) are credited and that the original publication in this journal is cited, in accordance with accepted academic practice. No use, distribution or reproduction is permitted which does not comply with these terms. 